\title{
Cysteine-Rich Protein 2
}

National Cancer Institute

\section{Source}

National Cancer Institute. Cysteine-Rich Protein 2. NCI Thesaurus. Code C104940.

Cysteine-rich protein 2 (208 aa, $22 \mathrm{kDa}$ ) is encoded by the human CRIP2 gene. This putative transcription factor may play a role in differentiation of smooth muscle tissue. 